\title{
Science Communication and Open Access: The Critique of the Political Economy of Capitalist Academic Publishers as Ideology Critique
}

\author{
Manfred Knoche \\ University of Salzburg, Salzburg, Austria, manfred.knoche@sbg.ac.at, \\ http://www.medienoekonomie.at, \\ https://kowi.uni-salzburg.at/ma/knoche-manfred/ \\ @Medoek
}

\begin{abstract}
Starting from a theoretical and methodological foundation of an academic ideology critique, the production, distribution and valorisation of science communication will be analysed in exemplary fashion. The focus is on the criticism of publishing houses' business models in the sphere of open Access publishing. These models are propagated and implemented by science and politics. Thus, academic publications continue to be traded as commodities. The existing relationships of power and domination are thereby reproduced. In contrast, the emancipatory potential of non-commercial science communication based on the digitalisation of production and distribution is shown.
\end{abstract}

Keywords: critique of science, science policy, science communication, Open Access, ideology critique, critique of capitalism, critical communication studies

Acknowledgement: A shorter version of this article was first published open access in German: Manfred Knoche. 2019. Kritik der politischen Ökonomie der Wissenschaftskommunikation als Ideologiekritik: Open Access in Ideologie, Kritik, Öffentlichkeit ed. Uwe Krüger and Sebastian Sevignani, 140-174. Leipzig: Publikationsserver der Universität, DOI: https://doi.org/10.36730/ideologiekritik.2019.8

The German version was expanded into a longer English version. Translation from German to English by Christian Fuchs.

\section{Preface}

\section{By Christian Fuchs}

Capitalism reproduces its fundamental structures of capital accumulation by changing itself. It is based on a dialectic of continuity and change and the dialectic of the productive forces and the relations of production. Digital capitalism has emerged from capitalism's dialectical development. Manfred Knoche's article covers a particular aspect of the critique of the political economy of digital capitalism - the critique of the political economy of open access.

The very term 'open access' promises an opening up and radical change of the publishing industry. But publishing capital has transposed itself into the realm of open access, creating open access capital and open access capital accumulation models. A new capitalist openness industry has emerged. Today, openness is a capital accumulation model. Manfred Knoche situates open access in the context of the interaction of the capitalist economy and public universities. 
Knoche provides a critical analysis of open access' political economy that utilises the tradition of ideology critique. He stresses that ideology critique and critique of political economy are not two separate forms of critique but are two dialectical poles of Marxist critique. Knoche shows how various actors who intend to advance the "openness" of publishing support and justify the profit interests of the capitalist openness industry and thereby produce and reproduce an open access ideology. It becomes evident the openness ideology and open access as ideology are a crucial ideological moment of the open access industry's capital accumulation models.

Capitalism is not just in its internal structural dynamic dialectical and antagonistic. Capitalism is also based on a dialectic of immanence and transcendence. The very structures that differentiate and reproduce capitalism also create potentials that undermine capitalism, emancipatory potentials. Marx $(1857 / 58,853)$ calls these potentials "germ[s] of newer historic forms". Digital capitalism contains potentials that point beyond itself. In the realm of open access, we not just find capitalist open access but also alternative, emancipatory, non-profit, non-capitalist potentials, projects, journals, books, publishers that are germs of future historic forms of publishing, the economy, and society. Digital capitalism is grounded in an antagonism between digital capital and the digital commons. Manfred Knoche analyses this dialectic as antagonism between capitalist open access and emancipatory open access. The second are minority projects that face the power of capitalism and therefore often struggle to survive. The germs of the new do not automatically blossom into fully developed flowers. More often they wither away. There is no automatic development of the economy and society.

Humans make society and history based on the conditions they find themselves thrown into. Progressive potentials can only be developed and realised through praxis. Emancipatory open access' seeds will only develop into a "living flower" (Marx 1844, 176) by practical movements that challenge the power of capital in the publishing industry, the media industry, the economy and society. Radical Open Access is the attempt to bring together projects that have an alternative vision for open access (see http://radicaloa.disruptivemedia.org.uk/communards/, http://radicaloa.disruptivemedia.org.uk/about/). The journal tripleC: Communication, Capitalism \& Critique is part of the Radical Open Access initiative. Emancipatory open access has to start as the critique of capitalist open access. Emancipatory OA models are not green or yellow, they are diamond models of open access because the commons are the good society's most precious resource (see Fuchs and Sandoval 2013).

Manfred Knoche's article is an important reading for everyone who cares about the public and common good in society and the academic world. It shows why emancipatory open access is urgently needed.

\section{References}

Fuchs, Christian and Marisol Sandoval. 2013. The Diamond Model of Open Access Publishing: Why Policy Makers, Scholars, Universities, Libraries, Labour Unions and the Publishing World Need to Take Non-Commercial, Non-Profit Open Access Serious". tripleC: Communication, Capitalism \& Critique 13 (2): 428-443. https://doi.org/10.31269/triplec.v11i2.502 Marx, Karl. 1857/58. Grundrisse. London: Penguin.

Marx, Karl. 1844. Contribution to the Critique of Hegel's Philosophy of Law: Introduction. In Marx Engels Collected Works (MECW) Volume 3, 175-187. London: Lawrence \& Wishart. 


\section{Academic and Socio-Political Context of the Problem}

"The conditions cry out for ideology critique"

(Jaeggi 2009, 271)

This article develops perspectives for critical communication and media theory on the basis of approaches that are grounded in Marx's Critique of Political Economy (Marx 1859, 1867, 1885, 1894), use Marx and Engels' German ideology (Marx and Engels $1845 / 1846$ ), and stand in the tradition of critical social theory. In this context, the discussion of ideology theory and critique focuses on the aspect of social criticism as a critique of capitalism ${ }^{1}$ (Iber 2005; Heinrich 2005; Krämer 2015).

Because of the social significance of the connection between domination, power, ideology, and (false) consciousness in bourgeois-capitalist societies, which is relevant to both theory and practice, ideology critique, especially from the point of view of the critique of capitalism (Butollo and Nachtwey 2018), is one of the most important fields of research in academic analysis and critique.

Accordingly, ideology critique is also at the centre of a critique of the political economy of media, journalism and communication studies as a fundamental theoreticalempirical critique of science that is yet to be developed. The theoretical basis for this is a negative-critical concept of ideology, which stands in contrast to ideology as a worldview and to a neutral concept of ideology applied in the sociology of knowledge. The orientation towards a negative-critical concept of ideology includes a view of ideology as false consciousness, which ties in with the Enlightenment tradition of thought.

Here "especially Marx's analysis of commodity fetishism is regarded as an example of academic thought that is capable of exposing and overcoming all ideological, i.e. false ideas that arise from this fetishism" (Koivisto and Pietilä 1993, 234). The essential aim of ideology critique is therefore "to determine the ideological nature of the various phenomena of consciousness, meanings, discourses, practices, etc. through their relationship to the maintenance of and/or struggle against society's power relations" (Koivisto and Pietilä 1993, 238). In this sense, the production, distribution and reception of ideology in the media and culture-industry will also be critically examined and evaluated, especially under the aspects of the anti-democratic stabilisation, legitimisation or concealment of

- economic, political and cultural power and power relations as well as of

- social inequality and injustice.

My contribution focuses on the theoretical-methodological foundation of an academic ideology critique, which can also be used as a guide for further ideology-critical analyses in the field of media and communication studies. On the basis of this foundation, I present an exemplary ideology critique of the interdisciplinary inter-/multidisciplinary problem of science communication $(\mathrm{SC})^{2}$, in the narrower sense of the so-called

1 The relevance of a critique of capitalism in the context of open access was also (acknowledged) by the then Managing Director of De Gruyter Verlag, among others. He considers it proven "that Open Access has become a business model and has largely lost its potential as a counter-model to scholarly publishing houses that is critical of capitalism" (Fund 2011, 157).

2 Unfortunately, the term science communication has also been used in media and communication studies for science journalism and science PR. However, the notion of science 
academic publication system. I do this in the certainty that the production and communicative processing of knowledge are central areas of activity in professional work in all academic disciplines. For this reason alone, a critique of the ideology of the organisation and products of SC is a relevant subfield of a critique of science in the context of critical science studies.

Due to the high importance of SC, the lives of critical communication scholars - just like scholars from all other academic disciplines - are fundamentally affected by the current process of change in the structural and content-related social conditions for SC. In this respect, the individual, collective and institutional (future) decisions and actions of academics are always also - beyond the justified individual career aspect science policy contributions to structural and content-related changes in SC. These contributions are relevant in the context of the political-economic, social and cultural development of society as a whole.

Accordingly, the following scholarly analysis and explanation is deliberately guided by the socio-political impetus, in conjunction with ideology critique, to provide a radical (going to the roots) critique of the past, present and future domination of SC by the science-politically legitimized and (also financially) supported - traditionally hegemonic symbiosis of profit-oriented publishers and mainstream academia. On the basis of this criticism, the potential for liberation or emancipation and the possibility of the real transformation of SC, with which the existing power and domination relationships can be overcome, is to be demonstrated. This is especially true from the point of view of critically changing the hitherto dominant market-driven content of SC's products, in the narrower sense of scientific publications.

The aim of this contribution is therefore to analyse the empirically observable changes and processes of change in SC towards Open Access (OA) and to explain them theoretically in such a way that active emancipatory change by the 'actors concerned' is made possible on the basis of comprehensible findings. The hitherto dominant analytical approach of a seemingly 'value-free' science is not appropriate for this purpose, since SC, like all areas of society, is to a large extent politically, legally and economically controlled by powerful interests and is therefore fundamentally contested.

In addition, structural changes in SC, which are currently being discussed, legitimised and gradually institutionalised in practice within the larger framework of the Open Science Initiative (Heise 2018), are also part of media and communication studies. Contrary to their real social, societal, economic and political significance, the media of academic books and journals have - unlike the press, radio, television, audio, video, music and social media - so far only to a limited extent been the focus of theory-building and empirical research in media and communication studies. This is especially true for theories and studies in one of the currently central research areas in media and communication studies, namely the one focused on media change.

communication is more comprehensive. It goes even beyond scientific publications and thus also beyond the currently narrow discussion on open access.

3 In this article, ideology critique of Open Access is concentrated on the hitherto dominant form of Open Access theory and practice, which is oriented towards publishing business models. In contrast to this, the article will show the possibilities of non-commercial Open Access in science communication. 


\section{Theoretical-Methodical Approach of Analysis}

In view of the inadequacies of existing analyses of the problems of OA-SC, which are mostly limited to symptom and surface criticism, I take the apparently contradictory, but in reality dialectical foundations of the ideological theory and criticism of Marx and Engels as the theoretical-methodological starting point of my analysis. These foundations are also a permanent central reference point for (ideology-)critical sociology, psychology, political science, philosophy and economics.

In the works of Marx and Engels, ideology critique and critique of political economy generally merge into one another ${ }^{4}$. Within social philosophy and sociology, Marx's critique of capitalism as a whole can be treated as ideology critique (Jaeggi 2009, 273). The critique of political economy "is social theory, and it can be read as a critique of the objective thought forms that the bourgeois social formation has produced [...] In this sense, Capital is an ideology critique, although the term ideology does not appear in it" (Herkommer 2004, 83).

The task of an ideology critique of capitalism is, among other things, a normative distinction between true and false, imprecise, one-dimensional, distorted conceptions and practices that serve to legitimize power (Fuchs 2016, 42-44). In accordance with the chosen theoretical-methodological research approach, however, not only the relatively few explicit, sometimes inconsistent statements of Marx and Engels on the problem of ideology are relevant, but in the broadest sense the manifold theoretical-empirical analyses presented by Marx $(1867,1885,1894)$ as a comprehensive critique of political economy.

In this analysis, I include - as also stressed by Butollo and Sevignani (2018) in their historical-materialist analysis of digital capitalism that oriented on Marx's work - fundamental problems of the development of the capitalist mode of production such the contradiction or interrelation of productive forces and relations of production as relations of ownership, valorisation, distribution and class.

Only by means of the theoretical-empirical-historical analysis of the dominant capitalist mode of production and the underlying relations of production, distribution and valorisation based on the development of the productive forces, an elementary discrepancy with the propagated, mostly idealistic norms and values and thus their ideological content becomes apparent. The existence of this discrepancy can also be analysed in respect to the social and societal realm of SC.

Priority is therefore given to a critical analysis of the social reality or practice of the applied mode of production and relations of production conceived in this way (figure 1). Only on this basis can the ideological content of dominant ideas, concepts, goals, norms, values, promises, etc. in the context of SC's (re)organisation by OA be revealed and criticised in order to reveal the real relations of power and domination. The propagation and practical implementations of OA can thus be characterised above all as theoretical-practical applications of ideologies of concealment, distraction and justification.

4 "Critique of political economy is therefore at the same time one of the forms - and the central one - in which Marx carries out ideology critique" (Lenk 1972, 148). 


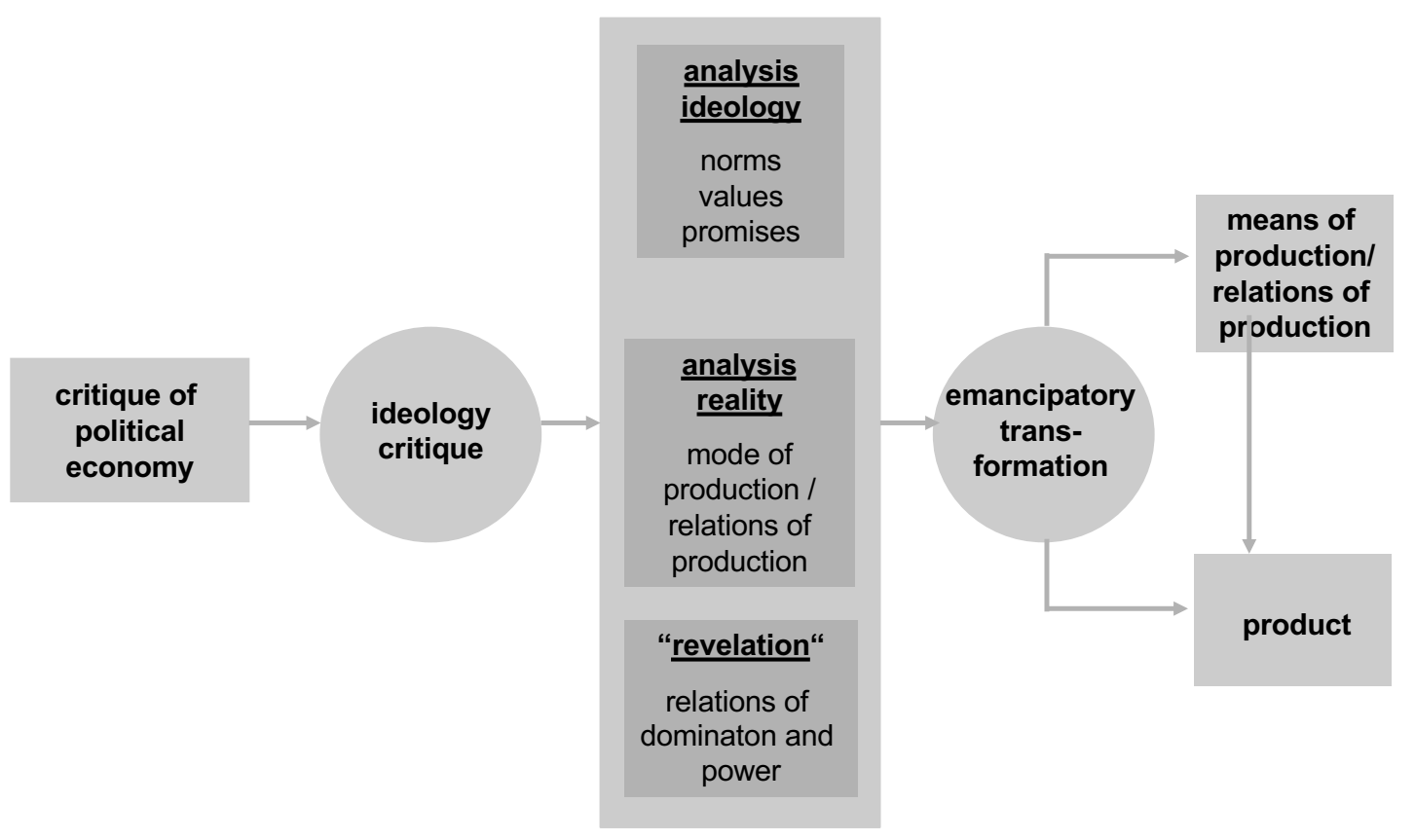

(c) Knoche 2018

Figure 1: Theoretical-methodological approach to ideology critique

Thought that is based on Marx's critique of political economy is fundamentally confronted with a multitude of conflicting schools of thought, some of which are diametrically opposed readings and interpretations of Marx's critique of capitalism. Hoff (2016, 170-310) provides comprehensive critical insights into the international history of Marxist approaches, with a particular emphasis on the critical perspective of the New Marx Reading (Hoff 2016, 311-334). In my opinion, this approach is also suitable as a basis for a critique of the ideology of SC. For in contrast to other approaches, especially to Marx's interpretation in traditional Marxism-Leninism, "the New Marx Reading insists only on the fact that the inner (as opposed to the apparent) context of social conditions is not directly transparent and that these conditions are themselves inverted forms of appearance. According to Marx, revealing this inner context and deciphering the objective mystifications and the inverted and fetishized manifestations of societal conditions is a specifically scholarly achievement" (Hoff 2016, 335)

In general, my reflections on ideology critique also tie in with the approach of an expanded theory and analysis of the culture industry of the so-called Frankfurt School (Critical Theory) "with a double reference to Marx. The authors take up his basic concepts by explicating the commodity character of culture, and they develop it further by analysing the production and reception of culture, to which Marx had given little consideration, as realms of the ideological stabilisation of domination" (Martin 2018, 168).

In critical analogy to the theory and analysis of the culture industry (Horkheimer and Adorno 1947/2002), I address the obvious (industrial) capitalisation of science as part of the culture industry. The dominant forms of capitalist production and distribution of academic products as commodities have the consequence that knowledge production and distribution, just like media production and distribution, are in principle subject to the laws of the capitalist mode of production, especially valorisation and profitability.

Subject-specific points of departure for this analytical approach are works on the development of a critique of the political economy of media and communication (Fuchs 
2017; Knoche 2002; Sevignani 2016). In this way, the revelation of the reality of regularities, i.e. of the essence of the capitalist reproduction process in the form of social relations of production, ownership, valorisation, distribution, transport, power and domination, can also be achieved for the media and communication sector and in the related academic disciplines. Such an analysis functions as a reference point for ideology critique as a critical analysis of the 'veiling' of dominant (academic) ideas, views, conceptions, concepts, theories and explanations.

Ideology critique is neither a conservative-elitist cultural critique nor an end in itself, but rather aims at an emancipatory change of the social relations of production, distribution and transport, freeing them from power and domination. In addition, an emancipatory change in the content of products is to be achieved. Accordingly, I do not limit ideology critique to a critical discourse analysis for 'uncovering' the ideological content of intellectual products, i.e. ideological terms and texts. Nor is it about accusation, moral indignation and/or the unmasking and denunciation of persons who consciously or unconsciously produce or spread ideologies and act accordingly.

With this theoretical-methodological approach to ideology critique, therefore, ideology as such is not primarily criticised, "but a practice that is maintained by means of ideology or is constituted by it. In this respect, it [ideology critique] aims not only at the correction of epistemic errors, but also at the - 'emancipatory' - change of the situation" (Jaeggi 2009, 277). The aim is thus an interconnected double change of the social reality and above that a change of the (then no longer ideological) ideas and conceptions of this reality.

An essential starting point for such an ideology-critical analysis is also Marx's central insight that the communication of ideological elements is a real historical social necessity for the stabilisation and expansion of existing relations of power and domination. Ideology critique is matter of socially necessary appearances that are created with ideologies and in which surface phenomena obscure the real internal structure of society, essentially the actual relations of production and distribution (Schnädelbach 1969, 83-84). Explicitly or implicitly connected with ideology is also the ruling class' need to prevent liberation from these relations of domination and power. "Ideology is then essentially a deceptive generalization of partial interests" (Reitz 2014, 86), whereby thinking about alternatives is blocked.

The distinction presented by Titus Stahl (2013) between a cognitivist (epistemic) and a materialist (socio-critical), non-epistemic conception is a guiding aspect of the ideology-critical analysis of SC. Stahl points out that the conception of ideology critique by Marx and Engels implies on the one hand a cognitivist conception with an idea of "false consciousness", whereby certain mental phenomena are criticised as ideology because of their untruth or because of epistemic deficiencies. On the other hand, Marx and Engels criticised the understanding of ideologies as mere mental errors that lack truth. They practice a radically alternative approach, a praxis-theoretical ideology critique that has an emphasis on ideology critique as social critique:

"The innovation of Marx's theory of ideology consists rather precisely in presenting an alternative approach that focuses on a materialistic analysis of social forms of ideas instead of an epistemic critique. [...] We can therefore understand ideology critique as a critique of practices. This determination of ideology critique [...] can also accommodate the cognitivist intuition that ideologies are untrue" (Stahl 2013, 229). 


\section{Ideology Critique of the Practices of Open Access Science Communication}

The method of ideology critique I use consequently serves to point out a decisive discrepancy between the practical reality of social facts or conditions and the prevailing ideological ideas or representations of them. The primary aim is to prove the practical effectiveness of this reality for the corresponding ideological production. The focus of such ideology critique is consequently the structural critique of "structural domination" (Jaeggi 2009, 295) with the aim of dismantling this domination in the realm of societal practices and, beyond that, in the realm of the production of ideology.

\subsection{The Interaction of Base and Superstructure}

In the following subsection, ideology critique is specifically applied to the current discussion on $\mathrm{OA}$ and the corresponding practical implementations of $\mathrm{OA}$. My analysis is primarily concerned with scholarly explanations of the dominant restructuring and reorganisation of SC. I use Marx's approach of a primarily structural explanation in the context of the capitalist mode of production: "For him, politics is dependent on a mode of production in which certain (class) interests inevitably dominate over others [...], and a clear awareness of this context is prevented by ideology" (Reitz 2014, 83).

In my reality-centred ideology critique by means of the qualitative-empirical analysis of the theory and practice of observable OA activities, I use the central categorical terms defined by Marx and Engels (Herkommer 1985, 53ff): mode of production, productive forces, relations of production (RP) ${ }^{5}$, relations of intercourse (Verkehrsverhältnisse), relations of domination, base and superstructure. In the context of ideology critique, these terms serve as the categorial framework and yardstick of the investigation. In addition, ideology critique also examines the extent to which the findings of Marx and Engels are also applicable to the selected object of investigation. In this context stands the for the most part bitterly debated political question of whether Marx is right. Eagleton (2018), for example, gives a well-founded positive answer to this question.

The problem of the relationship between base and superstructure (Tomberg 1974; Harman 1986) is generally relevant with regard to the social (revolutionary) development within capitalism and also with regard to the possibilities of capitalism's transformation to socialism or communism. But the base/superstructure-problem is also of great importance in the context of ideology critique, and consequently also in the ideology critique of $\mathrm{SC}$ with a focus on $\mathrm{OA}$.

The previous academic debate on the base-superstructure theorem suffers from simplifying, diametrically opposed, monocausal approaches that either postulate (absolute) cause, conditionality, determination, influence, domination or determination of the superstructure by the base or vice versa. In addition, the attribution of social phenomena to the base and/or the superstructure diverges in these two, largely mechanical-deterministic approaches.

One problem is that the two opposing positions usually each refer to Marx and Engels, but arrive at different interpretations on the basis of different readings and the one-sided selection of single statements/texts. These positions develop their own theories on the basis of this selection, with more or less critical distance or opposition to the works of Marx and Engels. In order to characterise the relationship between base

5 The term 'relations of production' (RP) includes relations of distribution. 
and superstructure, Marx and Engels have made seemingly contradictory statements, which are expressed in the following two key quotes ${ }^{6}$.

\section{Apparent Dominance of the Base}

"The totality of these relations of production constitutes the economic structure of society, the real foundation, on which arises a legal and political superstructure and to which correspond definite forms of social consciousness. The mode of production of material life conditions the general process of social, political and intellectual life. It is not the consciousness of men that determines their existence, but their social existence that determines their consciousness" (Marx 1859, 263).

\section{Apparent Dominance of the Superstructure}

"The ideas of the ruling class are in every epoch the ruling ideas: i.e., the class which is the ruling material force of society is at the same time its ruling intellectual force. The class which has the means of material production at its disposal, consequently also controls the means of mental production, so that the ideas of those who lack the means of mental production are on the whole subject to it. The ruling ideas are nothing more than the ideal expression of the dominant material relations, the dominant material relations grasped as ideas; hence of the relations which make the one class the ruling one, therefore, the ideas of its dominance" (Marx and Engels 1845/1846, 59).

These two quoted complexes of statements by Marx/Engels appear to be contradictory, since

- the first quote emphasizes that humans' social existence, conditioned by the mode of production of material life, determines their consciousness (tendency: base determines superstructure),

- in the second quotation, on the other hand, (based on a historical analysis) the dominance of the power of the thoughts of the respective ruling class is placed at the centre of analysis tendency: superstructure determines base), while at the same time the power of material interests is presented as determining ideology production (tendency: base determines superstructure).

However, in my opinion, it is evident that the distinction between base and superstructure according to Marx is not based on a contrast of the material (base) versus the spiritual and mental (superstructure), which is often wrongly assumed by Marx' critics. Nor is the relationship between base and superstructure characterised as a monocausal relationship, i.e. not as a simple relationship of cause and effect, either in one direction or the other. Rather, both are merely relatively autonomous spheres that are permeated with both material and spiritual elements that are mutually effective in conjunction with each other (Tomberg 1974, 43ff).

"According to this, the economic structure of society is the real base upon which a legal and political superstructure rises, and to which certain forms of consciousness correspond" (Herkommer 2004, 81). It is about a structural connection between the

6 I do not use these quotations as "striking evidence" for the "correctness" of my investigative approach, but to demonstrate the contradictions of these statements by Marx and Engels, which in my opinion are only apparent. 
base and the superstructure (Bader et al. 1976, 37-38), characterized as a correspondence or condition relationship, where material production conditions the ideal and institutional superstructure of the law, the state and the social, political and intellectual life process. As Engels $(1890,1894)$ emphasizes, neither economism nor determinism is associated with this, but rather the material base becomes effective "in the last resort" (Engels 1884, 131).

As a result of a structural-empirical analysis, the actual (inner) relationship between base and superstructure in the theory and practice of OA-SC can be characterised as a regular, permanently reciprocal multidimensional process of effects and repercussions (reciprocal conditionality), of action and retroaction. This interaction is characterised by a combination of related developments and activities that are oriented in the same direction and take place both in the base and the superstructure The decisive basis of this interaction is the fact that the main actors regularly coordinate each other in order to powerfully represent their interests both in the superstructure and the base.

The permanent starting point or trigger for changes in the superstructure are the changes at the base, which are consciously and purposefully driven forward and constantly to be further developed in the interest of optimal capital valorisation and accumulation, in the form of elementary, above all technological changes in the productive forces (digitalisation of the means of production/work and the associated increase in labour productivity as well as the digitalisation of the means of communication, especially the Internet). These changes require and make possible elementary changes in the organisation of the production and distribution processes. The change in the productive forces acting as a driving force initially comes into conflict with the existing conditions of production, distribution and valorisation that have inhibiting effects, so that these conditions' elementary restructuring and reconfiguration up to their transformation is necessary in publishing houses' interest in optimal capital valorisation.

The theoretical and practical activities in the superstructure correspond to this new constellation or the tension at the base. In other words: the changes at the base require a change in the ideal and material superstructure corresponding to these changes. Theoretical and practical considerations on the (future) order and design of OA-SC therefore do not fall from the 'heaven of ideas' as independent (idealistic) ideas, but are decisively influenced and accordingly shaped by the practical changes at the base.

For the enforcement of this special interest of profit-oriented publishing houses, a fundamentally uniform production of ideology as a common interest on the part of the sciences (including libraries and funding organisations) and politics (not least the EU) is extremely conducive, if not decisively necessary. In this way, the danger of the in principle much more 'open' use of digitalisation and the Internet for alternative OA-SC without commercial publishers and without "quality control" on the part of traditionally established science is averted.

Academic and political organisations and the vast majority of academics and politicians have so far proved to be valuable allies for capitalist publishers. With the practical implementation of the given OA business models, they offer ideological flank protection $^{7}$ by consciously or unconsciously creating the wrong impression that they are,

7 An illustrative example of the production of such an ideology is the contribution by Herb (2017), which presents itself as is an assessment of open access, and which, contrary to reality, is entitled "Open Access between Revolution and Cash Cow" (in German: "Open Access zwischen Revolution und Goldesel"), although the reality is that academic open access is a "cash cow" (an unscientific, rather populist metaphor) instead of an alleged "revolution". 
based on their idealistic ideas, originally and continuously the motor of a quasi-revolutionary movement for all-round openness of academia in the interest of society as a whole. This misjudgement of reality also includes the fact that moral criticism of the negative excesses of publishers' OA business practices of publishers (excessive publication fees) acts in an ideological manner, giving the false impression that academia and politics are pushing through and taking forward OA against the interests of publishers.

In 2003, the Max Planck Society, the German Federal Ministry of Research and the German Research Foundation (DFG), among others, organised the Berlin Open Access Conference. At the conference, "calculations were presented that it would be much cheaper to fund data input (for academic journal articles) centrally and then to output it in a decentral manner free of charge than if each subscriber paid for journals, whether in print or online form, separately at a very high price" (Saur 2011, 270).

Thus, the main focus was on solutions to the problem of the much-cited 'journal crisis' or 'library crisis', which in real terms still consists of the fact that, due to commercial scientific publishers' exorbitantly inflated sales prices ("monopoly prices"), academic libraries are no longer in a position to subscribe to all or the most important journals, i.e. to fulfil their procurement obligations to a sufficient extent. Under the metaphor of Open Access - ideologically functionalised in line with (basically under misuse) the originally emancipatory Open Source movement - a redistribution within public budgets was initiated to solve the problem: instead of decentralised payments to publishers from the budgets of the many academic libraries, centralised payments from the budgets of science funding organisations and universities. This corresponds both to the interests of the libraries to be able to better fulfil their procurement obligations and to the interests of large publishers, who are complaining about the 'library crisis' and the increase in free information on the Internet: "This led to the fact that in 2003, for the first time in my forty years as head of a publishing house, I had to experience a decrease of turnover and a considerable drop in profits" (Saur 2011, 216).

The type and direction of the models and action-guiding concepts developed in the superstructure are decisively determined by the balance of forces that exist at the base and in connection with it in the superstructure. The actual public conflict between the principally possible emancipatory transformation and the necessary stabilisation of the existing relations of production, distribution and valorisation (including legal relations) is therefore extremely minimal. This corresponds to the real balance of power with a strong dominance of the coordinated, basically uniform cooperation of proponents of a publisher-bound OA-SC.

This interaction is based on a distinctly unified alliance of interests that aims at stabilising the existing relations of domination and power in SC and, to this end, at preventing the abolition of these relations. This interest results in the necessity of producing ideologies in the form of ideas and statements that on the one hand defend or conceal the existing relations of production, distribution and valorisation and on the other hand justify and legitimise OA models that are oriented towards the capital accumulation models of commercial publishers.

Within the framework of this common basis of interests, the partial resolution of conflicts is largely limited to apparently internal conflicts within the alliance of interests. There are partially (slightly) diverging interests of the conflicting parties (!) - under the guise of normative idealistic exaggerations. These conflicts are limited to the discussion of publishing houses' different business models (Heise 2018, 90ff; Herb 2012, $12 \mathrm{ff})$. The production of ideology thus diverges in part due to partially diverging inter- 
ests. This divergence depends on the social position of the representatives of the interests of publishers, libraries, academics, academic organisations, and science funds. Depending on the interests involved, diverging priorities are articulated with regard to the previously restricted choice of three OA business models (gold, hybrid, green). The discussion of institutional non-commercial repositories is limited to publications that have been realised in the first instance by publishing houses, which includes the question of whether and under what conditions the publishers as rights holders (copyright) allow preprints and postprints (secondary publications) in institutional and general repositories.

It is not difficult to see that the pathways that national states and the EU have so far taken in cooperation with universities and commercial publishers almost without exception can be characterised mainly as access business models that use publishing fees (Knoche 2014c). For some time now, the Gold Open Access route has been uniformly propagated and implemented worldwide as the 'silver bullet'. Essential for the above-mentioned process of interaction between the base and the superstructure is the fact that the ideological ideas of OA-SC developed in the superstructure are effective as concrete guidance for the implementation of $O A$ at the base, i.e. for the practice of SC.

Commercial publishers, university libraries, governments, political institutions and scientific funding organisations have to date determined the programmatic introduction of an OA paradigm for SC, its practical implementation, its content, and organisation 'from above' in a central manner. From the outset, the coordinated initiatives in this area have been aimed primarily at driving forward the restructuring and reconfiguration of the conditions of production and distribution required by the market economy as a result of a 'technological revolution' (digitalisation and the Internet). In the superstructure, this involves conceptual legal and organisational changes, in accordance with the necessities arising from the base due to changes in the productive forces. The adjustments of the relations of production (RP) to the development of the productive forces that are considered necessary are 'conceived' in the superstructure and practically implemented in the base.

These restructurings are mainly oriented towards the greatest possible fundamental homogeneity of interests of a coordinated alliance of

- large private academic book and journal publishers' interests in valorisation and power in coordination with

- the interests of political institutions (e.g. EU) in domination and steering (regulation, governance),

- academics' and their funding organisations' (e.g. DFG) career interests and interest in being hegemonic,

- academic libraries' interest in expanding their held resources.

The decisive factor here is that the existing relations of power and domination in the form of the prevailing relations of property, valorisation and production are not changed fundamentally and in a revolutionary way. Therefore, the production of ideology is also designed to delegitimise alternative, free OA practices that are technically possible, and to obstruct and circumvent such practices, and to admit them at best as 'niche projects'.

In order to achieve both the adaptation of SC-OA to the existing rule of public-private partnerships of academia and profit-oriented (large) publishers and the prevention of basic alternatives (where no publishers are needed and there is no control of the publishing process by mainstream peer review), the production of ideology is in a certain way necessary, but not decisive. What is decisive is the real practical organisational 
implementation within the existing structures of SC, i.e. the coordination between academic organisations (such as universities, libraries, scholarly societies, funding organisations), political institutions, and profit-oriented publishing houses. Such implementations strengthen the commodity character of academic products and publications.

3.2. The Capitalist Mode of Production's Production, Distribution and Valorisation Process: Open Access Business Models of Profit-Oriented Academic Publishing Houses VS. Non-Profit Open Access Universities

Figure 2 shows the general production and distribution processes of the different forms of OA-SC, which are also valorisation processes. The figure also compares the dominant business models of profit-oriented publishers to the thus far hardly used model of non-profit open access (where there are no commercial, for-profit publishers). Irrespective of the details shown, one must observe for all forms of OA that they all feature fundamentally same production stages in the production process that is an academic work process. These stages are:

- the scholarly research (theory and empiricism) on which a publication is based,

- creation and composition as the design of the content and formal features of products that take on the form of manuscripts that are ready for print and digital download. This stage involves the formatting and layout of journals, monographs and anthologies.

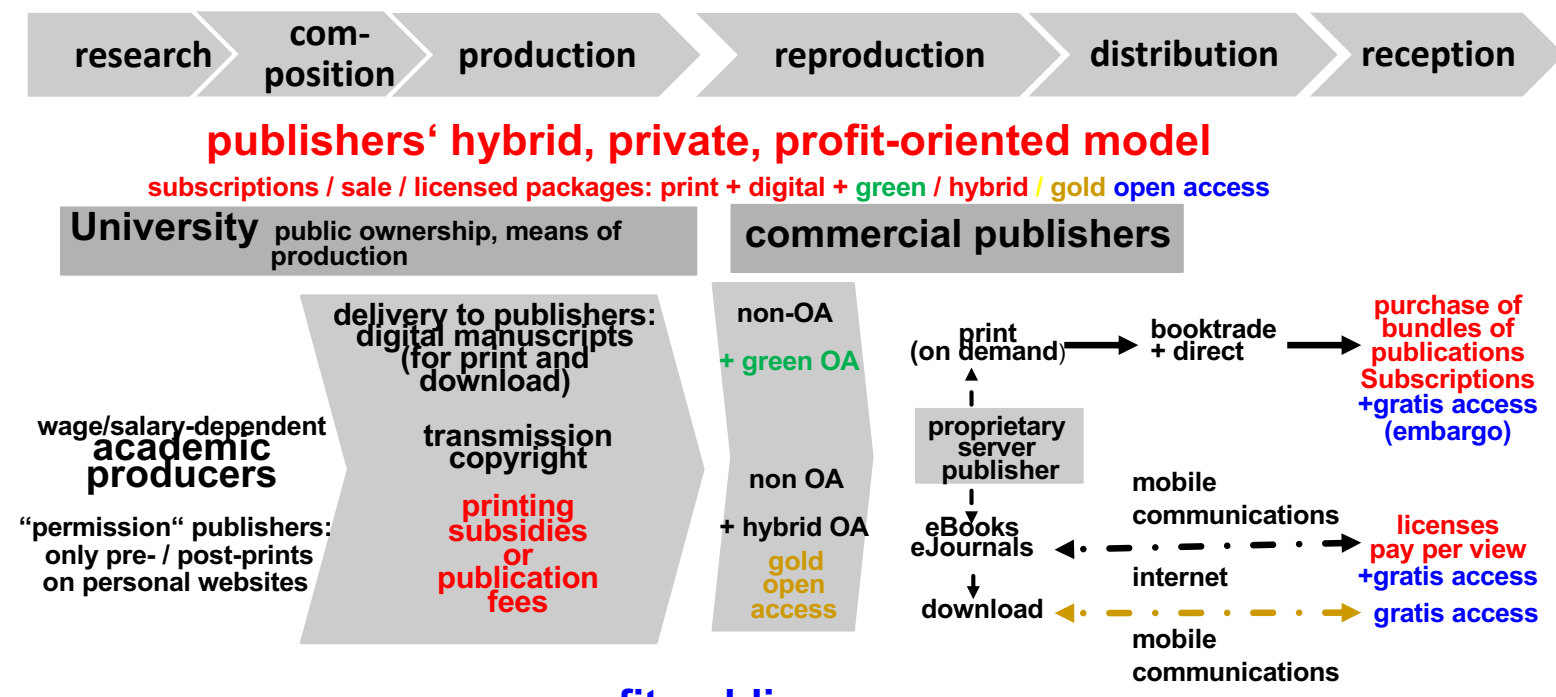

non-profit public open access

eBook / eJournal / eContribution + print on demand
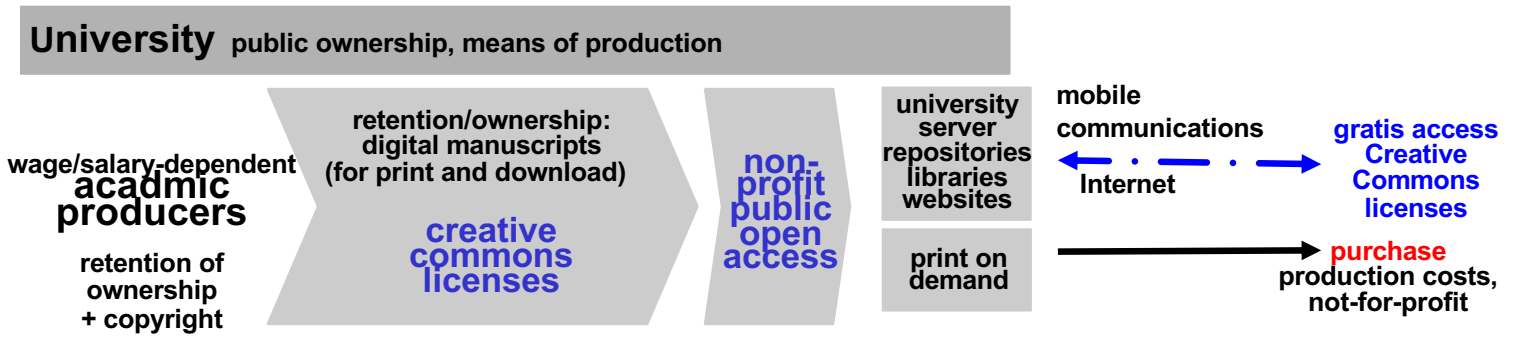

Figure 2: The production, distribution and valorisation process of publishers' toll open access (non/gold/hybrid/green) VS. (university) public open access 
One of the key aspects is this: The work (usually) done by state universities' employees and civil servants on the basis of many years of research (project) work that results in the production of publications is regularly financed by taxpayers' money. This means that the entire production process of academic publications is tax-funded. In the case of the dominant model of open access publishing, finished digital products and the associated property and valorisations rights are basically delivered and surrendered to capitalist publishers free of charge, i.e. these rights are given away.

The common basis for the theoretical and practical realisation of the technical, organisational and financial possibilities for the realisation of OA-SC, which have been enormously improved by digitalisation, is thus the fundamental retention of the conventional structure and concrete organisation of the process of academic production and distribution. This also includes the fundamental retention, but necessary partial restructuring of the publisher-bound reproduction and distribution processes and, above all, the valorisation processes. This is why the decisive, fundamental difference between capitalist OA-SC on the one side and OA-SC that is independent of capitalist publishers on the other side (the latter is shown in the lower part of figure 2) is 'systembusting' in that, in the course of a complete changeover of the entire academic publication process to OA-SC without capitalist publishers, the publishers that are already theoretically dispensable for OA-SC in theory today, would also be made superfluous in practice. However, this complete changeover would also make the traditional decentralised local university libraries largely superfluous in future.

Because of this common real existential threat, publishing houses and libraries are quasi natural partners in establishing an interdependent alliance that holds a common interest in the practical development of OA-SC that is based on commercial publishers. This common interest in OA-SC is, however, because of libraries' struggle for existence and publishers' need to valorise capital an ideological and legitimatory interest that wants to only minimally realise free OA-SC and simultaneously extensively expand 'paywalls' for ebooks and other electronic resources. Commercial publishers realise $\mathrm{OA}$ at best in three different forms, all of which involve substantial payments to publishers (Figure 2):

- as (exclusively digital) gold OA, where authors or universities/funding bodies pay publication fees,

- as a predominantly hybrid (print and digital) OA with double payments ('double dipping') of payments for subscriptions and copies of printed products plus payments for individual authors' publications that are published in digital format in open access journals and books,

- as green OA where there are payments for subscriptions and copies of printed products combined with digital OA after an embargo period (e.g. one year). This model can also involve digital preprints or 'secondary publications'.

However, the main mutual interest is still clearly directed towards stabilising the traditional subscription system for print publications (journal subscriptions and book sales), combined with the interest that has been prevailing for some time now in the parallel development of a new type of paid licensing system for electronic journals and electronic books. The complete conversion from print to digital products in the near future is neither in the mutual interest of commercial publishers and libraries, nor - at least not at present - in the interest of the overwhelming majority of academics.

The effective mode of operation of the ruling fourfold alliance of publishers, libraries, academia and politics becomes visible in the production of ideology and in practice: there is the obstructive de-legitimisation and de-qualification of alternative forms of OA- 
SC that are independent of capitalist publishers and universities as well as the defamation of new pure OA publishers as 'predatory publishers'.

The currently dominant form of OA-SC, which is tied to commercial publishing houses, primarily serves - ultimately for existential reasons of the participants - the political-economic goal of consolidating and strengthening the existing relations of power and domination, for which especially the securing of the conditions of publishing houses' conditions of valorisation and the cooperation between politics, academic and publishing houses conducive to valorisation are regarded as positively functional for the common interest of the participants (see Knoche 2014b, 2014c with details on the publishing houses' design of the product diversification and the associated diversification of the business relationships with university libraries as customers with fixed customer obligations).

The capitalist form of OA and SC has not only serious negative economic consequences for universities, but above all negative consequences in terms of the content of academic production that becomes the capitalist production and distribution of goods. The capitalist form of OA and SC furthermore also has negative impacts on academics' professional success. Through commodification, the publishing houses that are declared as renowned 'brands' not only obtain the intellectual property rights of academics as creators in order to valorise capita, but also control the organisation of academic quality management by selectively controlling access to the publication market (that is carried out free of charge by academics who are selected by the publishing houses as editors of journals and anthologies and as peer reviewers).

Instead of the hitherto dominant sale of physical products (printed goods) as property for use, the licensing of access to non-physical services (downloads) for shortterm consumption, where property rights and products remain on proprietary servers owned by capitalist publishers, is gaining importance. What remains the same is the publishers' appropriation and valorisation of academic labour.

The restructuring, reconfiguration and partial transformations deemed necessary by OA advocates and especially by publishers on the basis of the development of digitalisation and the Internet will under the prevailing societal conditions be realised in the realm of SC (Hanekop and Wittke 2013) in the same way as in the media industry as a whole. This means above all that on the basis of a fundamental change in the form of products via digitalisation that includes universal de-physicalisation, de-temporalisation and de-spatialisation, combined with the corresponding enormous possibilities for rationalising production, distribution and consumption processes, far-reaching new possibilities for capital accumulation will be opened up for commercial academic publishing houses (Knoche 2013, 103-108).

In contrast to this development, the real possibilities of liberating OA from capitalist business models that are based on digitalisation and require the means of the decapitalisation $^{8}$ and de-commodification of SC (Knoche 2014a, 252 et seq.) could so far, due to the prevailing balance of interests and power, only be used to a marginal degree.

An essential function of any ideology is also discernible here: the propagation/legitimation/justification of 'innovations', combined with an false promise that academic freedom and scientific progress as well as quality would be promoted in the public

8 De-capitalisation does not mean the expropriation of for-profit-oriented publishing houses, but rather their becoming superfluous by actively liberating science communication from capitalist production methods that are based on the interest of valorising capital and the commodification of academia's products. In concrete terms this boils down to academics no longer publishing with commercial (large) publishers. 
interest via OA. However, with the dominant implementation of OA business models that stand in the interest of capitalist publishers (gold, hybrid, green), the realisation of competing emancipatory OA models, some of which stand in the interest of critical academics, is in reality marginalised or prevented.

Contrary to the constantly declared idealistic promises of 'opening' SC to the whole of society, the programmatic introduction of an 'OA paradigm' has so far in real terms primarily served the goal of legitimising the restructuring or reconfiguration (Hanekop and Wittke 2013) of the academic production and distribution system towards the interests of the private economic sector of book and journal publishers. Thus, from the perspective of the desirable emancipatory transformation of SC, a negative conclusion must be drawn for the time being:

"The implementation of Open Access (OA) as a 'golden, green and hybrid road' of for-profit-oriented publishing houses is a momentous error, measured against the immense possibilities of an emancipatory transformation of SC on the basis of digitalisation and the Internet. In this way, the commodification (science as a commodity) and with it the traditional economic, legal and content-related dependence on the power of globally operating publishing oligopolies are strengthened" (Knoche 2014c, 76)

\subsection{Relationships of Production, Distribution and Valorisation as Relations of Domina- tion and Power}

"The crucial point is that the publisher retains the right to the content"

(Saur 2011, 272)

"[...] even professors who are not afraid of God or the Basic Law, not to speak of the people, tremble at the publishers' 'no'"

(Benseler 1969, 509)

Ideologic approaches to $\mathrm{OA}$ and $\mathrm{SC}$ veil the fundamental retention of the status quo of the RP as a balance of power and domination. Along comes on the one hand the justifications of changes (innovations) necessary to stabilise this status quo and on the other hand the de-legitimisation and practical prevention of alternative emancipatory changes. As a result of the concentration of OA solely on usage access for recipients, the generally necessary emancipatory opening of access for academics as producers are largely ignored.

The RP of OA-SC (figure 3) are, on the surface, very different from the usual capitalist RP in other economic sectors. The reason is that both the physical and intellectual production of goods and in the service sector the capitalist model of wage-labour combined with forms of formal and real subsumption of labour under capital continues to dominate (Marx 1867, 1023-1038; Mendner 1975, 30-36, 117-246, who distinguishes two phases of real subsumption, mechanisation and automation, instead of the distinction between formal and real subsumption). Subsumption under capital is the immediate and direct subordination and subjugation of the labour force as wage-dependent class and of the entire production process under the conditions of the valorisation of capital. This immediate subsumption is a decisive characteristic of the specific capitalist mode of production that is also fully effective as the universal-real subsumption of labour under capital in the current restructuring and transformation processes taking place in the media industry (Knoche 2013, 99-102). 


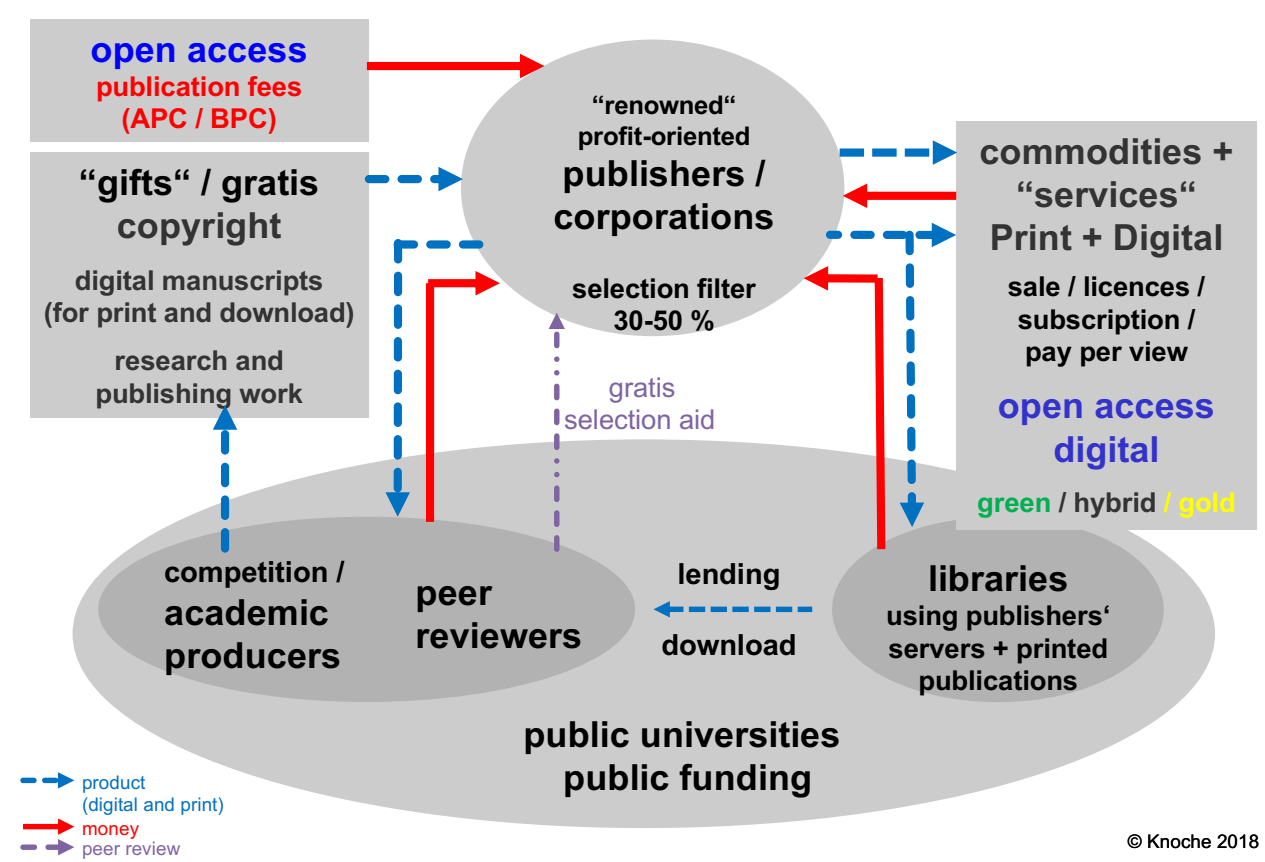

Figure 3: Relations of production/distribution/valorisation/power relationships

In contrast, there are some relevant peculiarities of the mode of production and the associated $R P$ in the field of SC that also have a dominant effect as special relations of intercourse, distribution and valorisation. To illustrate and explain these peculiarities, it may be useful to work towards a tendential expansion of the theory and critique of capitalism developed by Marx and Engels, as Sevignani (2019) suggests for the social phenomenon of "digital prosumption" (on digital prosumption see Fuchs 2010, 2014). As always, the aim is on the one hand to integrate current societal developments into the theory of Marx and Engels, and on the other hand to in a transcendent manner theoretically expanded the analysis of the (modern) societal problems that these two authors do not discuss or have only marginally discussed.

Marx's theory and empirical analysis is focused on the capitalist mode of production. He emphasises the industrial production of physical commodities on the basis of wage labour in the form of the real, i.e. direct and immediate subsumption of labour under capital in capitalist companies. For the realm of the production of non-physical goods, however, Marx states:

"Here capitalist production is only applicable to a very limited degree. [...]. Here things usually remain at the level of the forms transitional to capitalist production, where different scientific or artistic producers, artisanal or professional, work for a common merchant capital, the publisher; a relation which has nothing to do with the capitalist mode of production proper, and is itself not yet formally subsumed under it" (Marx 1861-1863b, 143-144).

Transitional forms are the relations of production and labour where the direct producers from outside the capitalist production process supply capitalist enterprises against payment or free of charge partly with semi-finished products that are technically processes in these enterprises, and partly with finished products that merchant capital sells. Therefore, academic producers' non-physical production of content results "in commodities which exist separately from the producer. [...] these people 
(where they are not independent) mainly work for merchant's capital, e.g. booksellers" (Marx 1867, 1048).

Subject to a more differentiated discussion, $a^{9}$ preliminary characterisation of the fundamental relationship between academic authors and academic publishers can now be made: According to Marx's distinction, the phenomenon of capitalist OA-SC is only a mediated and indirect subsumption of labour under capital (no formal or real subsumption) or unproductive labour that nevertheless is in a mediated and indirect manner productive labour for capital. Academic labour, in its basic function of the publishing activity, has unchanged for centuries, operated as being subsumed under commercial capital (also termed merchant capital) that is "perpetually buying and selling commodities", which is "its exclusive operation" (Marx 1894, 386). "The form M-C-M', buying in order to sell dearer, is at its purest in genuine merchants' capital" (Marx 1867, 266). In contrast to industrially producing capital, publishing capital functions as commodity trading capital, thus as merchant capital with commercial profit (Marx 1894, chapters 16 \& 17, 379-416).

What is decisive, therefore, is that the intellectual production of academics, especially since there is no separate physical reproduction in the production of digital products, is subsumed under the capitalist production of goods. In general, the following applies: "A writer is a productive labourer not in so far as he produces ideas, but in so far as he enriches the publisher who publishes his works, or if he is a wage labourer for a capitalist" (Marx 1861-1863a, 14). In a similar way to the intellectual activity of writers as producers of literature (Schwenger 1974, 98-100, 116-125), commercial publisher's appropriation, marketing and valorisation of the intellectual-material products of small commodity producers is characteristic of digital SC.

Historically, the profit-increasing advantage of the publisher over the merchant as a mere trader consisted first of all in the fact that the publisher no longer bought finished commodities from small producers, but instead commissioned production to small independent producers of commodities with a capital advance or delivery of raw materials, and only paid them so low wages for their work "that one portion of the labour-time performed remained unpaid. The putter-out thus came to appropriate surplus-value on top of his previous trading profit" (Marx 1894, 1043 [part of: Friedrich Engels' Supplement to Volume 3 of Capital]). Thus, profit was made by labour's surplus-value and commercial surplus-value (Boltanski and Esquerre 2019, 487-501).

The commissioning of small commodity producers has long been prevalent in literary production, sometimes with advance payments of fees, whereby 'freelance' writers because of the publishers' publishing programme plans, marketing analyses, analyses of competition, and marketing plans "are not the subject, but rather the object of a book plan, the concept of which was developed in the editorial offices" (Schwenger 1979, 47ff).

Capitalist academic publishers have perfected this extremely profit-increasing production method for by appropriating the products of the immediate small-scale academic producers and their intellectual property rights as valorisation rights free of charge or only by paying small fees. This method is in itself a form of exploitation, even if the producers do not work directly as wage earners in the publishing houses. The

9 A possibly necessary 'expansion' of Marx's theory and critique of capitalism, also with regard to scholarly communication including Open Access, would at least have to include the discussions of formal and real subsumption of (for capital) productive and unproductive labour producing commodities, of absolute and relative surplus value production, as well as of the distinctions between profit and rent (merchant capital, commercial profit), which is not part of this article. 
use-value of creative-intellectual products created in the public sector serves, through these products' transformation into commodities with an exchange value, to realise surplus-value in the accumulation of mercantile/commercial capital as monopoly profits in the form of 'information rents' (Krämer 2002, 642ff). This accumulation of capital would not be possible at all on the basis of academics working directly as wage earners in the publishing houses, i.e. it would be counterproductive, since the publications, most of which are based on many years of research work, would be "unaffordable" for the publishing houses.

Academic publishers function as part of the tripartite book trade system (producing book trade/publishing book trade, book wholesale/intermediate book trade, book retail/assortment book trade). The restructuring of the book trade in recent decades has been characterised by a decisive redistribution - increasingly based on the digitalisation of products - between university producers' production and reproduction labour performed and the wage-labour performed by workers dependent on selling their labour-power to capitalist publishers. Whereas traditionally in the print era (without the use of electronics and digitalisation), production services such as editing and reproduction services such as typesetting, creation of the printer's master copy, artwork preparation, printing and transport were provided or commissioned to other companies after the delivery of manuscripts by authors, these services have become completely dispensable in the case of digital products.

As a result, publishers have largely lost their traditional basis of legitimacy, at least in the realm of digital SC. At the same time, university producers have in principle achieved complete autonomy in terms of content, technology and organisation by ${ }^{10} \mathrm{be}-$ ing able to take over all the production, reproduction and distribution services previously provided by the publishers. The immediate academic producers can in principle now take on or organise such activities themselves with little cost and organisational effort. This means an independence of the capitalist production and distribution of commodities, as is currently still the case on the basis of the unnecessary transfer of property rights to commercial publishers.

Academics' continued disregard for and non-use of such independent publishing leads to the hardly bearable condition that the publishing houses have to only make a few clicks to upload a multitude of pdf files onto their servers that authors deliver free of charge and perfectly designed in terms of content and technology. The capitalist publishers can then license this multitude of files to a large number of libraries (guaranteed sales), academic and many others at a high price that they charge for limited downloads. Or they sell the content as downloads that are broken down by individual book chapters and journal articles.

In summary, the general characteristics of SC are:

- Production work is financed by taxes and carried out in the state-organised public sector by universities using public ownership of the means of production, i.e. in the public sector outside private companies.

- As employees or civil servants in the public sector, producers have the extraordinary privilege of holding individual property rights to their products in the form of copyrights. They are able to assert these rights accordingly. As individuals, they can therefore under their own name independently distribute and valorise the

10 In principle, this autonomy/self-employment was already possible in the print era (although it was much more cost-intensive) and was also partly realised, e.g. via public university publishing houses that were later privatised. 
products of their academic work that is paid for from public funds and carried out using publicly financed means of production. It is, for example, simply inconceivable and impossible for dependent journalists who work in private or public media companies (organisations) to distribute and valorise their products manufactured in the course of their work in an independent and individual manner rather than in companies owned by media capitalists.

- Paradoxically, however, these privileged academic producers seemingly voluntarily - in reality mostly under the pressure of the prevailing regime of academic qualification - cede their copyrights to commercial academic publishers.

- At the same time, they hand over their academic products to these publishers as originals, specifically as finished print or download templates, as products that they have produced in mostly collective, lengthy labour processes as a result of many years of research.

- The handover of academic products to capitalist publishers is usually even done free of charge for the publishers, i.e. as a kind of gift, although the products are manufactured by wage or salary earners paid by the state using publicly owned means of production.

- Private sector commercial publishers can thus appropriate products and property rights and, on this basis, exercise valorisation rights together with the rights for distribution, access and use.

- In addition, publishers make use of the free labour of academic peer reviewers and editors of journals, anthologies and book series.

- Finally, the publishers sell the products made available to them free of charge by academics to university libraries and a large number of individual customers worldwide at high prices. They make use of subscription and licensing systems.

- The basis of capitalist publishers' excessive prices and exceptionally high profits compared to other sectors of the economy is a virtually unique market constellation: there is the guaranteed free delivery of finished print/download originals due to the pressure to publish that rests on academics ('publish or perish') in connection with guaranteed sales to libraries with a pronounced procurement obligation to fulfil the task of making academic literature optimally available to the academic community.

All in all, the paradoxical reversal of the 'actual' balance of power, which could hardly be avoided in the print era due to the necessary power of capitalist publishers, is being unnecessarily consolidated for the digital era with electronic books and electronic journals as commodities that are almost free of charge for the publishers. However, this reversal is also in the interest of the traditional symbiosis of publishers and mainstream academics who use publishers as a basis for their hegemony and as a selection authority. Academic publishing is thus becoming even more than before a closed shop dominated by the select few.

Above all, the fundamental problem of the real commodity form (commodification) of SC is exacerbated. For "in the neo-liberal economy and society, universities and colleges are academic enterprises that produce knowledge and knowledgeable people with the greatest possible efficiency as products whose value can be realised in the corresponding market by selling them. The decisive factor is therefore not the usevalue but the exchange-value of the products" (Stapelfeldt 2007, 32). 


\section{Elements of the Emancipatory Transformation of Open Access Science Com- munication (OA-SC)}

The general dialectic or rather contradiction of SC's RP is that, precisely on the basis of the above-mentioned peculiarities in connection with the digitalisation of SC, there are extraordinary, quite real possibilities of emancipation from the existing power relations. In conclusion, therefore, as an alternative to the ruling model of OA-SC, some elements of an emancipatory transformation of SC that are possible in principle and have already been partially realised are presented in this section (Fuchs and Sandoval 2013; Knoche 2014c).

Initially, these elements are mainly directed towards the fundamental goal of a decapitalisation/de-commodification of SC and, above that, a fundamental change in the relations of production, distribution, valorisation and power. The structural and consciousness-related prerequisites for achieving the goal of such an emancipatory change in SC (not only with regard to publisher-independent OA) are much more favourable than the change potential for the media industry and journalism (Knoche 2014a), which I have begun to point out and which can be characterised as a "dialectic of the universal-real subsumption under capital and 'emancipatory potentials"' (Knoche 2013, 120).

The main characteristics of these exceptionally favourable conditions are:

- the principle autonomy of universities, colleges, and universities of applied sciences;

- the creation of digital knowledge products on the basis of the public ownership of the means of production (an infrastructure developed at the highest level);

- payment from public funds for production work and work previously done in publishing house;

- independent digital distribution via the Internet at low costs;

- enormous cost savings for academic libraries and thus enormous reliefs for the budgets of universities, colleges and universities of applied sciences (elimination of subscription and licence payments to publishers).

As early as 1996, a publication published by the Börsenverein des Deutschen Buchhandels in cooperation with library associations expressed concern that, on the basis of available digital networks, servers, phototypesetting and graphics software, laser printers and the like, "practically everyone is printing or distributing articles, books, software etc. themselves. at low costs and over long distances - 'lightning fast' and efficient" (Grötschel and Lügger 1996, 42). Reference was also made to the replacement of the traditional production process (academic only deliver manuscripts to publishers for further processing) by the free delivery of print-ready originals in phototypesetting quality. In addition, in the case of digital products there is no need for further material processing by the publishers.

A complete switch to OA without publishers, which is in principle possible, would also remove the following dominant elementary abuses and injustices:

- the free supply of knowledge products produced with payment from taxpayers' money as gifts to publishers for commercial valorisation;

- the free transfer of the property rights of the authors as copyrights for the publishers for the goal of commercial valorisation, thus blocking or restricting the authors' independent distribution and valorisation; 
- the publishing houses' momentous, irresponsible transformation of public goods into commodities, for which the exchange-value and profit-generation alone, instead of the use-value of the goods, is decisive, which is expressed in the respective publishing house's programme, by means of which in turn certain academic disciplines are more or less connected to the public;

- the madness that authors and libraries have to 'buy back' the products paid for from public tax money and given to the publishers free of charge, including property rights, from the publishers at maximum prices;

- and the associated enormous waste of taxpayers' money, which is in principle unjustified.

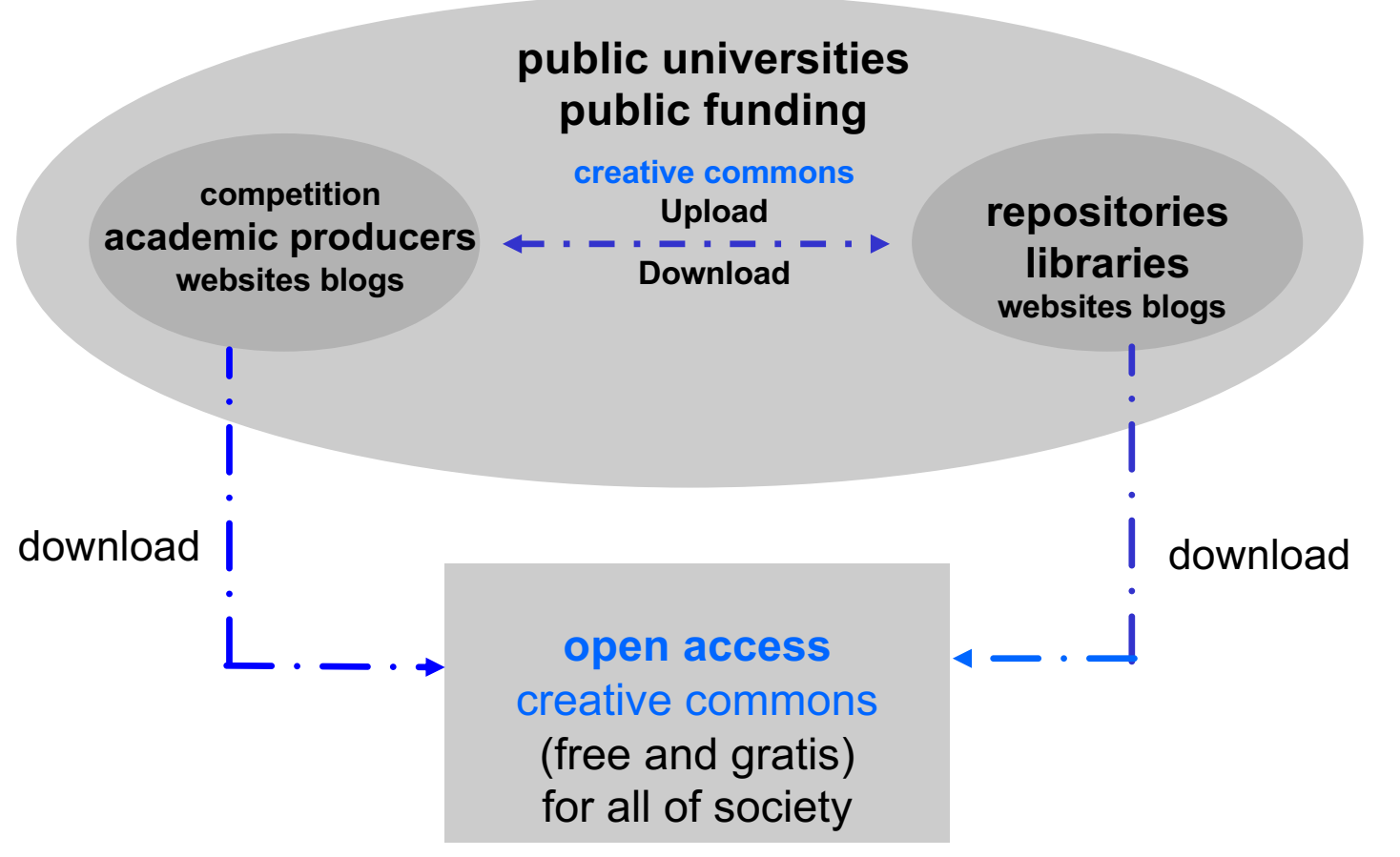

Figure 4: Open Access without profit-oriented publishers and without peer review institutional repositories and creative commons

Figure 4 illustrates the fundamental change of the conditions of production, distribution, consumption and valorisation in the case of a publisher-independent OA compared to the constellations outlined in figure 3.

Elements of a future emancipatory transformation of science communication are for example (Knoche 2014c, 78):

- the reorganisation of the obsolete academic quality regime, obsolete: quality assurance organised by publishers;

- libraries as repositories and publishers including print on demand, obsolete: publishers with proprietary publishing servers;

- public funding of publishing organised by universities, obsolete: subscription/licence fees and publication fees paid to publishers; 
- existence of only the non-profit open access model / de-capitalisation, obsolete: gold, hybrid, green OA business models of publishing houses;

- only one publication form of contributions (with varying length), obsolete: the formats of journals and books;

- collaborative interactive science communication, also via non-commercial social media (websites, blogs, Wikipedia), obsolete: private Google Books, Facebook, Twitter, ResearchGate, Academia.edu, etc.

However, the realisation and use of non-commercial OA projects without commercial publishers does not yet solve the fundamental problem of the actually prevailing form of SC that acts as a 'selection power'that orients the content SC and determines academics' career opportunities. Even in the probable case of the future increase of the number of non-commercial academic OA publications, the problem of the prevailing quality regime will remain, with the consequence that, as a rule, radically critical content will not be published open access and that alternative OA publications will not be recognised as providing professional qualifications.

It should be noted that a change of the relations of production and power cannot be achieved by or through mere individual changes in consciousness based on ideology critique. This is especially true for critical communication scholars who, due to their precarious employment conditions in the academic realm, are virtually forced to submit to the prevailing qualification regime even 'against their better judgment' in order to successfully survive academic selection procedures (peer review). For it would be naïve and 'suicidal' not to take into account that in the course of the inevitable competitive battles in the existing academic system, the chances of success for radical-critical work are due to the prevailing imbalance of power minimal at present and probably also in the near future

The dilemma that individuals working as dependent professionals in the academic sector, just like other dependent workers in other sectors, face is the fact that they are (often against their desires, wants and critical awareness) existentially forced "to reproduce the superstructures with the reproduction of material conditions and thus are both the creators and the creatures of ideologies, ideological apparatuses, practices and rituals" (Herkommer 1985, 140-141).

Therefore what is needed above all is that actors in critical communication studies organise solidary, political and practical efforts (struggles) focused on society as a whole and science policy that aim at the fundamental transformation of these existing conditions. What concrete (resistant, subversive) activities in this regard are strategically and tactically possible in reality - especially considering the relations of power and domination that are actually (manifest and latent, directly and indirectly) very effective also in the reality of media and communication studies - must be clarified in an unfortunately very difficult discussion process.

The prerequisite for such a transformation, however, is at least an actual willingness to change that is motivated by social critique and politics and based on an interaction of individual and collective societal interests and needs for a fundamental transformation of the prevailing structures and contents of SC that go beyond OA. In my opinion, for such a task a view that is critical of ideology and, beyond that, "critical of capitalism, is indispensable" (Draheim and Reitz 2010, 100). 


\section{References}

Bader, Veit Michael, Johannes Berger, Heiner Ganßmann, and Jost v.d. Knesebeck. 1976. Einführung in die Gesellschaftstheorie 1. Gesellschaft, Wirtschaft und Staat bei Marx und Weber. Frankfurt/New York: Campus.

Benseler, Frank. 1969. „Vor-Sätze zur Produktion von Literatur”. Kürbiskern. Literatur und Kritik 3 (69): 509-515.

Boltanski, Luc and Arnaud Esquerre. 2019. Bereicherung. Eine Kritik der Ware. Berlin: Suhrkamp.

Butollo, Florian and Oliver Nachtwey, Eds. 2018. Kritik des Kapitalismus. Schriften zu Philosophie, Ökonomie, Politik und Soziologie. Berlin: Suhrkamp.

Butollo, Florian and Sebastian Sevignani. 2018. Cyber-Marx? Ansatzpunkte einer historischmaterialistischen Analyse des digitalen Kapitalismus. In Marxismus und Soziologie. Klassenherrschaft, Ideologie und kapitalistische Krisendynamik, ed. Tine Haubner und Tilman Reitz, 251-275. Weinheim Basel: Beltz Juventa.

Draheim, Susanne and Tilman Reitz. 2010. Dagegen sein im System der Neutralisierungen. Der Kapitalismus gegen seine Befürworter verteidigt. In Grenzverschiebungen des Kapitalismus. Umkämpfte Räume und Orte des Widerstands, ed. Karina Becker, Lars Gertenbach, Henning Laux and Tilman Reitz, 75-102. Frankfurt am Main: Campus.

Eagleton, Terry. 2018. Why Marx Was Right. New Haven, CT: Yale University Press.

Engels, Friedrich. 1894. Letter to Walter Borgius, 25 January 1894. In Marx Engels Collected Works (MECW) Volume 50, 264-267. London: Lawrence \& Wishart.

Engels, Friedrich. 1890. Letter to Joseph Bloch. 21-22 September 1890. In Marx Engels Collected Works (MECW) Volume 49, 33-37. London: Lawrence \& Wishart.

Engels, Friedrich. 1884. The Origin of the Family, Private Property and the State. In the Light of the Researches by Lewis H. Morgan. In Marx Engels Collected Works (MECW) Volume 26, 129-276. London: Lawrence \& Wishart.

Fuchs, Christian. 2017. Die Kritik der Politischen Ökonomie der Medien/Kommunikation: ein hochaktueller Ansatz. Publizistik 62: 255-272. DOI: http://doi.org/10.1007/s11616-017-0341-9

Fuchs, Christian. 2016. Reading Marx in the Information Age. A Media and Communication Studies Perspective on "Capital Volume I". New York: Routledge.

Fuchs, Christian. 2014. Digital Prosumption Labour on Social Media in the Context of the Capitalist Regime of Time. Time \& Society 23 (1): 97-123.

Fuchs, Christian. 2010. Fuchs, Christian. 2010. Labor in Informational Capitalism and on the Internet. The Information Society 26 (3): 179-196.

Fuchs, Christian and Marisol Sandoval. 2013. The Diamond Model of Open Access Publishing: Why Policy Makers, Scholars, Universities, Libraries, Labour Unions and the Publishing World Need to Take Non-Commercial, Non-Profit Open Access Serious". tripleC: Communication, Capitalism \& Critique 13 (2): 428-443. https://doi.org/10.31269/triplec.v11i2.502

Fund, Sven. 2011. De Gruyter Open Library - Das Open Access-Modell eines Universalwissenschaftsverlags für Bücher und Zeitschriften. In BIBLIOTHEK Forschung und Praxis 35: 157-160. DOI: http://doi.org/bfup.2011.021

Grötschel, Martin and Joachim Lügger. 1996. „Neue Produkte für die digitale Bibliothek: die Rolle der Wissenschaften. In Die unendliche Bibliothek. Digitale Information in Wissenschaft, Verlag und Bibliothek, ed. Börsenverein des deutschen Buchhandels e.V., Die Deutsche Bibliothek, Bundesvereinigung Deutscher Bibliotheksverbände, 38-67. Wiesbaden: Harrassowitz.

Hanekop, Heidemarie and Volker Wittke. 2013. Der Wandel des wissenschaftlichen Publikationssystems durch das Internet. Sektorale Transformation im Kontext institutioneller Rekonfiguration. In Internet, Mobile Devices und die Transformation der Medien. 
Radikaler Wandel als schrittweise Rekonfiguration, ed. Ulrich Dolota and Jan-Felix Schrape, 147-172. Berlin: sigma.

Harman, Chris. 1986. Basis und Überbau (Base and Superstructure). International Socialism 2 (36): 3-44. https://www.marxists.org/deutsch/archiv/harman/1986/xx/basueber.htm

Heinrich, Michael. 2005. Kritik der politischen Ökonomie. Eine Einführung. Stuttgart: Schmetterling. Third edition.

Heise, Christian. 2018. Von Open Access zu Open Science: Zum Wandel digitaler Kulturen der wissenschaftlichen Kommunikation. Lüneburg: meson press.

Herb, Ulrich, Ed. 2012. Open Initiatives: Offenheit in der digitalen Welt und Wissenschaft. Saarbrücken: universaar.

Herb, Ulrich. 2017. Open Access zwischen Revolution und Goldesel. Eine Bilanz fünfzehn Jahre nach der Erklärung der Budapest Open Access Initiative. Information, Wissenschaft \& Praxis 68 (1): 1-10.

Herkommer, Sebastian. 2004. Metamorphosen der Ideologie. Zur Analyse des Neoliberalismus durch Pierre Bourdieu und aus marxistischer Perspektive. Hamburg: VSA.

Herkommer, Sebastian. 1985. Einführung Ideologie. Hamburg: VSA.

Hoff, Jan. 2016. Befreiung heute. Emanzipationstheoretisches Denken und historische Hintergründe. Hamburg: VSA.

Horkheimer, Max and Theodor W. Adorno. 1947/2002. The Culture Industry: Enlightenment as Mass Deception, In Dialectic of Enlightenment, 94-136. Stanford, CA: Stanford University Press.

Iber, Christian. 2005. Grundzüge der Marx’schen Kapitalismustheorie. Berlin: Parerga. Jaeggi, Rahel. 2009. Was ist Ideologiekritik? In Was ist Kritik?, ed. Rahel Jaeggi and Thilo Wesche, 266-295. Frankfurt am Main: Suhrkamp.

Knoche, Manfred. 2014a. Befreiung von kapitalistischen Geschäftsmodellen. Entkapitalisierung von Journalismus und Kommunikationswissenschaft aus der Sicht einer Kritik der politischen Ökonomie der Medien. In Journalismus ist kein Geschäftsmodell. Aktuelle Studien zur Ökonomie und Nicht-Ökonomie des Journalismus, ed. Frank Lobigs and Gerret von Nordheim, 241-266. Baden-Baden: Nomos.

https://www.uni-salzburg.at/fileadmin/multimedia//Kommunikationswissenschaft/documents/Aktuelles/MedPolitik/Knoche final.pdf

Knoche, Manfred. 2014b. OPEN ACCESS Alb+Wunsch-Traum of an advocate of a truly free non-profit scholarly communication, distributed as pamphlet at the 59. annual conference of the German Communication Association (Deutsche Gesellschaft für Publizistik- und Kommunikationswissenschaft, DGPuK). Passau, May 28-30, 2014. https://www.uni-salzburg.atffileadmin/multimedia/Kommunikationswissenschafftdocuments/Aktuelles/MedPolitik/DGPuK2014 Passau Knoche.pdf

Knoche, Manfred. 2014c. Emanzipatorische Transformation der Wissenschaftskommunikation statt Irrweg Verlags-TOLL OPEN ACCESS. MedienJournal 38 (4): 76-78. http://eplus.uni-salzburg.at/obvusboa/content/titleinfo/1761063

Knoche, Manfred. 2013. Krisenhafte kapitalistische Produktionsweise als Triebkraft für Restrukturierungen und Transformationen (in) der Medienindustrie. Erklärende Theorieelemente einer Kritik der politischen Ökonomie der Medien. In Langfristiger Wandel von Medienstrukturen. Theorie, Methoden, Befunde, ed. Wolfgang Seufert and Felix Sattelberger, 87-111. Baden-Baden: Nomos. https://uww.uni-salzburg. atfilieadmin/multimedia/Kommunikationswissenschaftddocuments/Aktuelles/MedPolitik/Knoche SeufertSattelberger Nomos2013.pdf

Knoche, Manfred. 2002. Kommunikationswissenschaftliche Medienökonomie als Kritik der Politischen Ökonomie der Medien. In Medienökonomie in der Kommunikationswissenschaft. Bedeutung, Grundfragen und Entwicklungsperspektiven, ed. Gabriele Siegert, 101-109. Münster - Hamburg - London: LIT.

Koivisto, Juha, and Veikko Pietilä. 1993. Nachwort. Der umstrittene Ideologiebegriff. W.F. Haugs Theorie des Ideologischen im Vergleich. In Wolfgang Fritz Haug: Elemente einer Theorie des Ideologischen. Argument-Sonderband AS 203, 233-246. Hamburg: Argument.

Krämer, Ralf. 2015. Kapitalismus verstehen. Einführung in die politische Ökonomie der Gegenwart. Hamburg: VSA. 
Krämer, Ralf. 2002. Informationsrente - Zur politischen Ökonomie des Informationskapitalismus. In Das Imperium des High-Tech-Kapitalismus, Das Argument. Zeitschrift für Philosophie und Sozialwissenschaften 248: 637-651.

Lenk, Kurt. 1972. Marx in der Wissenssoziologie. Studien zur Rezeption der Marxschen Ideologiekritik. Neuwied and Berlin: Luchterhand.

Martin, Susanne. 2018. Kulturindustrie und Herrschaft. In Marxismus und Soziologie. Klassenherrschaft, Ideologie und kapitalistische Krisendynamik, ed. Tine Haubner and Tilman Reitz, 168-182. Weinheim Basel: Beltz Juventa.

Marx, Karl. 1894. Capital. Volume Three. London: Penguin.

Marx, Karl. 1885. Capital. Volume Two. London: Penguin.

Marx, Karl. 1867. Capital. Volume One. London: Penguin.

Marx, Karl. 1861-1863a. Economic Works 1861-1863: Economic Manuscript of 1861-63 (Continuation). Marx \& Engels Collected Works (MECW) Volume 3. London: Lawrence \& Wishart.

Marx, Karl. 1861-1863b. Economic Works 1861-1864: Economic Manuscript of 1861-63 (Conclusion). Marx \& Engels Collected Works (MECW) Volume 34. London: Lawrence \& Wishart.

Marx, Karl. 1859. A Contribution to the Critique of Political Economy. Part One. In Marx \& Engels Collected Works (MECW) Volume 29, 257-417. London: Lawrence \& Wishart.

Karl Marx and Friedrich Engels. 1845/46. The German Ideology. Critique of Modern German Philosophy According to Its Representatives Feuerbach, B. Bauer and Stirner, and of German Socialism According to Its Various Prophets. In MECW Volume 5, 15-539. London: Lawrence \& Wishart.

Mendner, Jürgen H. 1975. Technologische Entwicklung und Arbeitsprozeß. Zur reellen Subsumtion der Arbeit unter das Kapital. Frankfurt am Main: Fischer.

Reitz, Tilman. 2014. Politik und Ideologie der bürgerlichen Gesellschaft. In Marx für SozialwissenschaftlerInnen. Eine Einführung, ed. Ingrid Artus, Alexandra Krause, Oliver Nachtwey, Gisela Notz, Tilman Reitz, Claudius Vellay, and Jan Weyand, 83-107. Wiesbaden: Springer.

Saur, Klaus G. 2011. Traumberuf Verleger. Hamburg: Hoffmann und Campe.

Schnädelbach, Herbert. 1969. Was ist Ideologie? Versuch einer Begriffsklärung. Das Argument 50: 71-92.

Schwenger, Hannes. 1979. Literaturproduktion. Zwischen Selbstverwirklichung und Vergesellschaftung. Darmstadt and Neuwied: Luchterhand.

Schwenger, Hannes. 1974. Schriftsteller und Gewerkschaft. Ideologie, Überbau, Organisation. Darmstadt and Neuwied: Luchterhand.

Sevignani, Sebastian. 2019. Digitale Arbeit und Prosumption im Kapitalismus. In Marx und die Roboter. Vernetzte Produktion, Künstliche Intelligenz und lebendige Arbeit, ed. Florian Butollo and Sabine Nuss, 293-310. Berlin: Dietz.

Sevignani, Sebastian. 2016. Kritische Politische Ökonomie. In Handbuch Medienökonomie, ed. Jan Krone and Tassilo Pellegrini, 1-28. New York: Springer. DOI: http://doi.org/10.1007/978-3-658-09632-8 3-1

Stahl, Titus. 2013. Ideologiekritik als Kritik sozialer Praktiken. Eine expressivistische Rekonstruktion der Kritik falschen Bewusstseins. In Nach Marx. Philosophie, Kritik, Praxis, ed. Rahel Jaeggi and Daniel Loick, 228-254. Berlin: Suhrkamp.

Stapelfeldt, Gerhard. 2007. Der Aufbruch des konformistischen Geistes. Thesen zur Kritik der neoliberalen Universität. Hamburg: Dr. Kovac.

Tomberg, Friedrich. 1969/1974. Basis und Überbau. Sozialphilosophische Studien. Neuausgabe. Darmstadt and Neuwied: Luchterhand.

\section{About the Author}

Manfred Knoche is professor emeritus of media economics at the University of Salzburg in Austria. He studied journalism, sociology, political science and economics at the University of 
Mainz and the Free University of Berlin. He obtained his PhD (1978) and defended his habilitation (1981) at the Free University of Berlin. He was research assistant in the years 19741979 and assistant professor for communications politics in Berlin in the years 1979-1983. From 1983-1994, he was professor of media and communication studies at the Vrije Universiteit Brussel in Belgium, where he was also the director of the Centre for Mass Communications Research. From 1994-2009 he held the chair professorship in media economics at the University of Salzburg in Austria, where he was Director of the Media Economics Group at the Department of Media and Communication Studies. He chaired the German Association for Media and Communication Studies' (DGPuK) media economics-section. He is author of many publications on the critique of the political economy of the media. His work has especially focused on the critique of the political economy of media concentration and the media industry's structural transformations.

http://www.medienoekonomie.at, https://kowi.uni-salzburg.at/ma/knoche-manfred/ Twitter: @Medoek 